\title{
RETHINKING MODERN EUROPEAN INDUSTRIAL POLICY: BEYOND THE CURRENT EU LEGAL FRAMEWORK
}

\author{
Dr. Matjaz Nahtigal, University of Primorska, Slovenia \\ matjaz.nahtigal@fm-kp.si
}

\begin{abstract}
The purpose of this article is to show that the current European Union (EU) legal framework is unnecessarily restrictive and unduly suppresses economic and developmental initiatives in many stagnating regions across Europe.

More innovative industrial policies, instruments and measures should be adopted in a highly decentralized manner across the EU. Between the 'laissez-faire' and 'dirigiste' approaches, there is significant room to maneuver for more pro-active industrial and development policies. New forms of industrial policies could and should be reinvented and implemented across the EU - not to harm or distort competition, but rather to further enhance it. More than one form and framework exist for a Single Market and for the competition policies.
\end{abstract}

Keywords: European industrial policy, 'old' and 'new' industrial policy, European legal constraints, regional development 


\section{INTRODUCTION}

The purpose of this article is to show that the current European Union (EU) legal framework is unnecessarily restrictive and that it unduly suppresses economic and developmental initiatives in many stagnating regions across Europe. In a growth-friendly context, various initiatives and development strategies based on local knowledge and local needs should stem from diverse European regions and member states.

If the EU genuinely intends to overcome the protracting economic, financial and social crisis and engage in economic reconstruction, modern types of industrial policy will have to be reinvented. This is true not only for the large parts of European regions and member states that suffer from protracting stagnation, lack of growth, high levels of unemployment and long-term loss of competitiveness but also for the advanced and successful European regions that want to remain competitive internationally.

Instead of remaining hostage to the dogma of free-market neutrality, the authorities at all levels of European polity should envisage the possibility of broadening and deepening access to markets for more people in more ways (Unger, 2007, p. 144). Spontenous market initiatives can be combined with the deliberate actions of public authorities. Rodrik (2011) pointed out that markets and governments are complements, not substitutes. High-quality public institutions and good governance of the public sector are the necessary conditions for the successful development of the market economy (Rodrik, loc. 196-208, Kindle edition).

The term industrial policy is used in its broadest sense to refer to any form of deliberate public activity - at the local, regional, national or supra-national level - that contributes to productive capabilities and improved competitiveness. The distinction between the 'old' type of industrial policy - predominantly in the form of state intervention in the markets - and the 'new' type of industrial policy - in the form of stimulating the creation of firms and promoting innovation and competitiveness (for the distinction between these types, see Bianchi \& Labory, 2006, p. xv) - will be taken into account in the discussion on the future of European industrial policy.

In the period when even British government officials like Vince Cable, the the Secreatary of State for Business, Innovations and Skills, state that "pure laissez-faire does not work" (Wintour and Mullholand, 2011), the debate on the possibilities of enhancing the role and scope of modern industrial policy in Europe should finally overcome the traditional ideology. The debate on the future of modern industrial policy in Europe should become a debate on the productive potential of industrial policy and on the strategic partnership between the public and private sectors. The future model should resemble the first 
period of European integration, with much more room for the member states and their regions to maneuver while running and developing their economies. The difference with the traditional industrial policy, however, is that the modern 'knowledge-based economy' requires substantially different policies and instruments in order to stimulate high value added, as well as innovative and flexible business practices, in comparison with the 'old' style of government interventionism.

The first part of this article will analyze the EU legal framework for industrial policy. The second part will examine the dogma of neutrality of the European Single Market. The third part of the article will discuss the possibilities to open up space for a plurality of industrial and development policies, using examples of successful regional industrial policies in some of the most advanced European regions. These examples are often neglected in discussions on the future of European industrial policy.

The examples of successful European regions will serve as a source of inspiration and encouragement to disseminate their successful practices to the stagnating European regions. The intention of this discussion is not to propose mechanical imitation of these regions, but rather to offer examples of of advance regions as a source of inspiration.

Finally, by analyzing the existing EU legal framework for industrial policy, this article aims to examine the most successful practices from advanced European regions in order to determine the ingredients and the risks associated with successful industrial policy, as well as how the European legal framework should be adjusted to the need for inclusive and balanced development from the perspective of stagnating European regions, member states and excluded parts of the European population. This adjustment should be made in such a way that opportunities will be opened up for all of the European citizens and businesses that are waiting in vain to experience the anticipated benefits of the laissezfaire version of a European Single Market.

\section{CURRENT EU LEGAL FRAMEWORK FOR INDUSTRIAL POLICY}

The current EU framework is primarily based on the concept of negative integration, which is characterized by the member states' gradual loss of many traditional economic powers and instruments. On the other hand, the process of positive integration in the form of harmonization at the European level took a gradual and different path. It has not replicated traditional instruments and powers at the supranational level but rather has focused on harmonization and the adoption of common standard. The debates regarding which areas, competences and instruments should be transferred to the European level have been a source of constant discussion and conflict, most notably during the Convention on the Future of Europe, which attempted to clarify divisions of competences and powers. 
The idea behind the Single Market version of European integration and completion is that the liberalized Single Market should provide immense benefits for its participants and actors. Assessments and estimates about the benefits of the Single Market were presented in the well-known Cecchini report "Europe 1992 - The Overall Challenge." This report calculated an enormous reduction of costs due to the removal of remaining barriers, enormous improvements of efficiency due to improved competition and economy of scale and a substantial boost of employment (Cecchini Report, 1988, p. 14).

In the context of the Maastricht treaty, these estimates and anticipated gains presented the basis for the completion of the Single Market, which was a key goal of European leaders and European institutions to which all other priorities, policies and instruments at the national and European levels should be adjusted. The less the governments would try to distort the Single Market, the faster the remaining barriers are being removed the greater would be benefits and efficiency gains emanating from the Single Market.

Other goals, such as the reduction of inter-regional disparities within the EU, the preservation of the social welfare at the level of member states, and the adoption of any form of industrial policy - in the form of either 'old' or 'new' industrial policy - could be employed only to the extent that doing so would not interfere with the completion of a Single Market. The completion of a Single Market has become a goal in itself. The motto for uncritical supporters of a European Single Market as the regional version of the free market continues to be that the more complete the Single Market becomes, the better things will be for everyone (Pelkmans, 2011).

In the context of the completion of a Single Market, industrial policy - which was already diluted because of the unclear division of competences and the general shift toward economic orthodoxy on the global and European level - has become constrained. More often than not, industrial policy has involved merely the lip service of European officials with little actual substance.

Article 157 EC (ex Article 130), which is dedicated to Industry, can be understood in the context of the Article 4 EC governing principle of 'open market economy with free competition.' As explained by Pelkmans (2006), both EU and its member states have committed themselves to the governing principle of internal market governance, which narrowed the scope for industrial policy: "[S]ince member states have explicitly agreed with this set-up, one could interpret the framework as a quasi-institutional denial to fall back on interventionist industrial policy in the future" (p. 60).

Even this highly constrained reference to industrial policy in Article 157 EC was very difficult to adopt during the Maastricht negotiation. The Article itself has an explicit 
limitation preventing the adopting of any measures which could lead to a distortion of competition.

The limitations of the scope of industrial policy in the European legal framework can be explained by the historical background of their institutional development, national preferences according to the 'varieties of capitalism' concept, and negotiation strategies behind the adoption of the article on industrial policies. The historical background of this topic was analyzed by Fioretos (2001), who pointed out that, before the Maastricht treaty, "the EC's industrial policy had primarily been designed for market liberalization and the abolishment of discriminatory subsidies, and nowhere could one find a statement suggesting that the Community have an activist and interventionist industrial policy" (p. 227). All of the key actors had in mind their own preferences and interests. Britain, for example, opposed the adoption of industrial policy because of its (at that time) superior performance "by enhancing market mechanism...thus, the primary concern for the British was to extend the economic area regulated by the EC in a fashion that would enhance the market mechanism and provide British firms with an environment they were accustomed to and that would ensure their competitive edge." (Fioretos, 2001, p. 231-232, footnotes omitted).

On the other hand, France advocated a more proactive industrial policy based on its dirigiste tradition of an interventionist industrial policy; together with Italy, France advocated for greater authority of the European Commission in the area of industrial policy to strengthen the competitiveness of European industry (Fioretos, 2001, p. 227). The attempt to 'trump competition policy' and the restrictions on state aid were also supported by the Belgian government (Church \& Phinnemore, 2002, p. 345).

Finally, Germany stood as another key actor between the maximalist French proposal and the minimalist British proposal. Germany was supportive of the insertion of an industrial policy clause committed to horizontal industrial policy and large-scale research projects. This was consistent with the German regulatory tradition in the area of industrial policy and with the German interests: "[T]he German position rests on regulatory principles of the coordinated market economy (CME), and the calculation that a limited EC industrial policy have beneficial effects for German producers in areas (especially high-tech) where the German market economy has been relatively weak" (Fioretos, 2001, p 238, footnotes omitted).

The background context of insertion of the article on industrial policy is particularly revealing for several reasons. First, it shows that the key actors in the EU acted on the basis of their preferences and the interests of the industries, as well as on the basis of the industrial policy tradition in the key member states. Second, the aim of the key member states was to secure or even improve the position of their industries on the internal market. Third, neither the balance between competition and proactive industrial 
policy nor the outcome of the crucial provisions of the Maastricht treaty and all subsequent treaties is objective and neutral; rather, these are the result of bargaining powers, national preferences and beliefs regarding how the governing principles and rules should shape a European Single Market.

Despite various attempts to substantially redefine the relations among cohesion, research and development, proactive policies and the undistorted markets, the conclusion is that the principle of undistorted competition enjoys primacy (Church \& Phinnemore, 2002, p. 346). In this highly constrained context, the EU and the member states did develop several instruments and policies in the areas of research, improved skills, innovations, and various schemes to support small and medium size enterprises (SMEs). On the other hand, sectoral and specific industrial policy almost entirely disappeared (Pelkmans, 2006, p. 73).

The European legal framework with respect to the role and scope of industrial policy has not changed significantly over the last two decades. During the Convention on the Future of Europe, the working group on economic governance under the chair Klaus Hänsch was established to explore, among other topics, the changes in the area of economic coordination, but it did not present any particular new proposal of enhanced cooperation with respect to industrial policy (see the European Convention, Final Report of the Working Group VI, 2002).

In the last two decades, sporadic attempts have been made to more strongly articulate industrial policy at the European level and the level of the member states. One such attempt was the report of former Dutch Prime Minister Wim Kok and others in 2003, when the EU was confronted with low rates of growth, increased unemployment and the unsuccessful implementation of the Lisbon treaty. In the report, the governments and the EU were urged to take a more proactive stand in the areas of infrastructure and knowledge. In Kok's foreword to the report, he stated that the member states must take primary responsibility to act and the EU must support them (Kok, 2003). The report also addressed the need to reskill workers in traditional industries in order to adapt to the needs of the 'knowledge-based economy' throughout the EU. As an example, the report mentioned the successful restructuring of Italian industrial districts with the help of small firm growth and the dissemination of knowledge and innovations among a network of firms (p. 25). However, even the occasional calls for more aggressive industrial policy across Europe, such as those offered by Kok, were described as "too little too late" by Pelkmans (2006, p. 66). 


\section{PERSISTENCE OF THE DOGMA OF NEUTRALITY OF A EUROPEAN SINGLE MARKET}

At the heart of the EU's framework is the belief that the European Single Market version of the free market, free of any distortion, will work most efficiently. They claim that in order to overcome the current protracted economic, financial and social crisis - which is the largest crisis since the beginning of the EU - it is necessary to implement more of a Single Market (Pelkmans, 2011).

However, proponents of the current version of the European Single Market as the best possible answer to all of the economic, financial and social difficulties in Europe tend to forget several things. First of all, they tend to ignore the fact that the existing European legal framework, which has been in place for the last two decades, is a result of bargaining powers, national interests and preferences rather than a result of the natural, neutral development of the European Single Market. There is no single best possible version of a market economy to which all countries should universally aspire in any given economic, social and legal context.

Second, the benefits from the established European Single Market, as stated in the Cecchini Report, were grossly overestimated. At the same time, and perhaps even more remarkably, the costs of the established European Single Marketsame were largely ignored. Any legal framework for the market economy creates distributional effects. As noted by Tsoukalis (2006), one of the leading experts on the European integration, a Single Market created 'winners' as well as 'losers': “Interestingly enough, the Cecchini report had virtually nothing concrete to say about the likely distribution of costs and benefits, apart from acknowledging the problem and expressing the hope that redistributive policies, supported by an active macroeconomic policy, would provide adequate compensation to losers or, even better, help weaker economies and regions to face the strong winds of completion unleashed by the elimination of barriers" Tsoukalis, 2006,(loc 657-62, Kindle edition).

Third, the last two decades, during which the current EU legal context of a Single European Market has been in place, do not represent the most successful period of European integration. In fact, the current context helped to create an increasing number of stagnating regions. The empirical evidence for this claim can be found in the latest edition of the Eurostat Regional Yearbook: "Out of the 271 NUTS level 2 regions in the EU for which data are available, the unemployment rate increased between 2007 and 2010 in 215 regions, remained unchanged in seven and fell in 49" (Eurostat Regional Yearbook, 2012, 78).

This evidence on European regional disparities clearly shows the strong impact of the economic and financial crisis in the EU, which makes the current framework of the European Single Market grossly inadequate to cope with the magnitude of the crisis. 
Without a comprehensive and proactive EU-wide response to the crisis, the entire EU project is becoming increasingly unsustainable.

Fourth, in the period when the existing EU legal framework was put in place, a major shift in the organization of production, from Fordist mass production to post-Fordist flexible production, occurred in many developed and developing countries around the world. Whereas the goal of Fordist production is to produce large quantities of standardized goods with the lowest possible costs to pursue economy of scale, the goal of post-Fordist flexible production is to produce small quantities of high value added products tailored to the needs of individual customers. This new type of production requires substantial changes in the organization of production, teams and firms, and also has important implications for supporting institutions, as it is based on constant innovations and improvements of products and technologies. Michael Piore and Charles Sabel, the pioneers in the area of flexible specialization, showed in their study that, contrary to conventional wisdom, Fordist mass production is not always the most efficient type of production. It can work efficiently in the context of stable demand; however, in the context of unstable, constantly changing demand, the flexible specialization can be a more efficient means of production and organization of production. The shift from Fordism to post-Fordism requires major organizational changes, changes in production and reskilling of workers, and it presupposes shifts in public policies and supporting institutions (Piore \& Sabel, 1984, p. 28-30). The shift from the 'old' to the 'new' type of industrial policy presents an important part of the shift from traditional Fordist mass production to the modern, post-Fordist type of production. It seems that, during the creation of the framework for a Single Market, the European decision-makers overlooked these important historical shifts in the areas of production, organization of production, competition, and supportive public institutions. Only a small number of advanced European regions or member states can be described as postFordist - that is, highly innovative, flexible, dynamic, cohesive and knowledge-based.

Fifth, following the above discussion, the more appropriate debate during the protracted European economic, financial and social crisis should not be whether we need 'more' or 'less' of a Single Market, but rather what kind of a Single Market European member states and their regions, businesses, entrepreneurs, employees and citizens really need. We need a more dynamic, more supportive environment, as well as institutions at various levels of European polity that can translate business ideas and enterprenurial initiatives into the practical market economy context.

We can conclude this chapter on the persistent dogma of neutrality of the Single Market by stating that the sooner we leave behind this dogma, the greater will be the chances for revitalization of a large part of the European regions and member states. In order to achieve institutional reconstruction, more diversity, more policy space, and more ideas 
and initiatives should grow from the bottom-up. Now that even the most free-marketoriented government in the EU, the UK government (or at least its State Secretary for Business, Innovations and Skills Vince Cable) is contemplating the need for new types of industrial policy, there is no reason for the EU legal framework to remain overly constrained and biased against the new types of industrial policy.

\section{RETHINKING THE MODERN EUROPEAN INDUSTRIAL POLICY}

In the process of integration through law, the EU and its member states have departed from the 'old' type of industrial policy to the highly constrained legal context of the weak type of industrial policy under the primacy of a Single Market. It has been widely accepted that the undistorted free market is the best guarantee for the efficiency and productivity of European economies. Two decades after the completion of a Single Market, the discussion should begin on how to revive modern, 'new' type of industrial policy all levels of European polity. Two decades after the adoption of the Maastricht treaty, it is becoming clear that the current particular version of a European Single Market may be beneficial for European retainable industries - that is, established industries effectively protected from new entrants due to high costs and lack of insufficient support for start-ups - but at the high cost of excluding almost everybody else.

The idea of the strong articulation of the 'new' type of industrial policy should begin to replace the dogma of neutrality of a European Single Market. There is evidence that many supportive institutions, instruments and policies to facilitate the restructuring are needed if increasingly large number of stagnating European regions and member states. The requirements to compete successfully in the period of the 'knowledge-based economy' are substantially more difficult than the requirements to compete successfully in the period of Fordist mass production. The former include, for example, a high quality of education provided to all citizens; strong labor market institutions providing training for constant reskilling; financial institutions providing and supporting the long-term development of highly innovative firms, especially small and medium size firms and start-ups; and many other supportive institutions and proactive policies.

The distinctive need to rethink European industrial policy for the twenty-first century began to be addressed by former Dutch Prime Minister Kok but was abandoned due to the virtual period of growth based on cheap credit before the European bubbles finally burst. The peripheral regions are paying an extraordinary price, and increasingly many of the core regions are doing so as well.

Before Kok's report, the importance of industrial policy was mentioned in the European Commission's (1993) white paper on "Growth, Competitiveness, Employment," which 
stated that "while industrial policy continues to be controversial no one is in any doubt as to the responsibility of governments and of the Community to create an environment as favourable as possible for company competitiveness" (p. 14). The subsequent development of European integration all but marginalized any development of industrial policies across Europe. However, today's record levels of unemployment, bleak labor market perspectives, low growth rates and large number of stagnating regions and member states clearly remind us that the time is ripe to revive European industrial policy.

What would the 'new' European industrial policy look like? First of all, it would be important not to repeat the one-size-fits-all technocratic approach without taking into account the immense diversity in terms of economic development and social cohesiveness. More innovative industrial policies, instruments and measures should be adopted in a highly decentralized way. The role of European institutions should be to maximize the maneuver room for regional and national experimentation in production and the organization of production (Unger, 2001, p. 3). Additionally, European institutions can learn from successful examples and disseminate them to other parts of the EU, not to mechanically imitate successful practices from one region to another, but rather to present successful examples as a source of inspiration and encouragement to other stagnating European regions (Unger, 2001, p. 3).

The 'new' European type of industrial policy, therefore, should be decentralized and participatory by invoking ideas and initiatives from local producers, should be pluralistic in order to adjust to the different needs and different productive potentials of different European regions and should be experimentalist in order to permanently adjust, correct and improve the strategic partnership between the private and public sectors. The shift toward modern types of industrial policy began with the shift from Fordist mass production to post-Fordist flexible production. On the other hand, European industrial policy, instead of trying to transform its 'old' type of industrial policy to the 'new' type of industrial policy, has mainly tied the hands of European institutions, national governments and regional authorities. The reliance on the Single Market in the last two decades trumped or diluted all other attempts to develop a more pro-active approach toward steering and developing the economy.

What has been mainly overlooked, ignored and legally suppressed in the European context is the transformation toward 'new' industrial policy, which has been pursued by some of the most advanced, innovative, competitive and cohesive regions around the world. The characteristics of the 'new' type of industrial policy were summarized by Best (1990) in his analysis of the emergence of post-Fordist regions engaging in what he described as The New Competition: "The New Competition can be distinguished from the old in four dimensions: organization of the firm, types of coordination across phases 
in the production chain, organization of the sector, and patterns of industrial policy. The New Competition is about strategic actions within each dimension. The term 'strategic' refers to market-shaping activities in contrast with market-reacting responses" (p. 11).

The comparative analysis of the emergence of The New Competion as one possible and advanced type of 'new' industrial policy shows that successful regions around the world -including Japan, the US, China and advanced European regions - have developed various new forms of cooperation and competition in the same segments of production.

The new form of industrial policy is both much broader, in terms of scope and instruments, and much less interventionist. Harvard Law Professor Roberto Unger and Tamara Lothian from Columbia University (2011), one of the leading proponents of new, transparent, innovative and imaginative forms of collaboration between the public and private sector, is convinced that the new types of industrial policy should be agnostic about sectors. In a joint piece on the possibilities to overcome the ongoing economic, financial and social crisis, among other proposals, Lothian and Unger (2011) advocate the need to reinvent industrial policy means to establish "a form of strategic coordination between governments and firms that is pluralistic, participatory, and experimental. Its aim is to help make the conditions and instruments of advanced production available to larger parts of the economy and the society" (p. 49). The focus of such a policy should be on small and medium size enterprises as the key source of jobs and output. More specifically,: "Its method should be the expansion of access to credit, to technology, to advanced knowledge and practice, to facilities for the organization of networks of cooperation that combine the benefits of flexibility of scale. Its characteristic concern should be to propagate successful organizational and technological innovations wherever they may arise" (p. 49). On this basis, Lothian and Unger have developed several components of modern industrial policy pursuing socially inclusive and broad-based economic development.

Perhaps the closest to the idea of decentralized cooperation as the new, reinvented form of industrial policy was achieved in some of the advanced European regions and member states. The examples of Emilia Romagna, Piedmont and other Italian regions should be mentioned, as should local public-partnerships in Ireland. Innovative policies and highquality education in Finland as a basis for entrepreneurial and technological progess offer further examples of successful European industrial policies (for more detailed analysis of advanced European regions, see Nahtigal, 2013).

Italian cooperative regions serve as examples of decentralized, flexible cooperation and partnership between the private and public spheres. They created a system that became known as the system of cooperation competition, in which dense networks of small and medium-sized enterprises in industrial districts cooperate and compete at the same time in the same segments of production. While this system may not be entirely compatible 
with the European rules of competition, in recent decades it has helped these Italian regions to develop one of the most advanced systems of production, innovation, cooperation, and competition in the world. The system is highly inclusive, and its level of social cohesion is at the highest level (Nahtigal, 2013, p. 612).

The problem with these examples across the EU is that, despite their potential broader implications, they remain limited to a very small number of advanced European regions. The true goal of EU economic and social recovery, therefore, is to expand and further innovate instruments and policies. It is this goal that has led to the call for fewer legal constraints at the European level and for more room to maneuver at the regional and national levels across the EU to implement the 'new' modern types of industrial policy. It should be noted that a Single Market and modern types of industrial policy are not necessarily mutually exclusive; the possibility to redefine certain tenets of a European Single Market depends on our common understanding of its content and legal framework. European regions and member states should not be left to the mercy of the invisible hand. They should not primarily depend on the European transfers, which are not allocated - at least not in sufficient amounts. It is not even feasible to have a Transfer Union to sufficiently support the excluded and stagnating European regions and member states. Instead, these regions and member states should be empowered and equipped to restructure and revive their economies and societies on the basis of their potential, initiatives and aspirations.

\section{CONCLUSIONS}

Between the laissez-faire and dirigiste approaches, there is a large amount of room to maneuver to develop more pro-active industrial and development policies. New forms of industrial policies can and should be reinvented and implemented across the EU - not to harm or distort competition but rather to further enhance it. More than one form and framework exist for both a Single Market and the competition policies. On the European level, a legal framework and policies should be adopted that would be able to steer between foreclosing and opening the markets and between negative and positive aspects of competitive policies. A new balance must be achieved, both at the European level and at the level of European regions and member states, to allow for more maneuver room, more space for development and more instruments and policy tools for the European regions and member states.

Advocates of modern, advanced forms of industrial polices have increasing put forth convincing arguments as to why industrial policy, especially in its modern form, should not be abandoned. In the last few decades, when industrial policy was mentioned or implemented, it was deemed as obsolete and outdated. During the protracted crisis, however, even the most developed countries in many cases returned to the instruments 
of 'old,' traditional types and 'new,' modern types of industrial policy. Examples include the restructuring of GM with the abundant help of the US federal government, the large support for 'green' investments in the car industry around the world, the various measures taken by the German federal government in the case of Opel and many other examples. Massive support for the financial institutions in the US and EU should also be mentioned in this context.

Ha-Joon Chang, professor of development economics from Cambridge University, argues for the adoption of a more balanced and subtle approach toward the theory and practice of industrial policy. Industrial policy has been an important instrument throughout economic history, and almost all of the leading industrial nations in the world have implemented it in various ways throughout their economic progress (Ha-Joon Chang 2009). As can be witnessed from the recent years of crisis, the most advanced countries in the world did not hesitate to return to various measures of industrial policy when they needed it. The existing legal constraints in the European and subsequently national contexts are increasingly difficult to defend theoretically and practically. The need to rebalance and redefine the constrained rules of a Single Market is becoming increasingly visible.

Of course, more space and more scope for modern industrial policy should not be viewed as a simple magic wand. It is only one additional instrument in an effort to revive ailing European industries and regions. A similar approach should be applied in the context of international trade rules.

On the other hand, industrial policy can be also ineffective. There are many examples of failed industrial policy efforts in both developed and developing countries. Modern types of industrial policy have additional safeguards, but there is no ultimate guarantee about its efficiency, which depends on many factors, including transparency and accountability of the policy-makers. For this reason, modern industrial policy has to steer between Scylla and Charibdis; as described by Unger (2007), it has to avoid the "twin evil" by steering between bureaucratic dogmatism and favoritism (p. 144-145). There is a distinct risk of abuse of the instruments and tools of industrial policy. Modern industrial policy presupposes high-quality public institutions with highly competent administration. It requires autonomy and accountability of the public administration to counter the pressures of various interest groups.

While there are dangers and risks involved in carrying out modern types of industrial policy, the alternative - doing nothing - almost certainly leads to continous stagnation. In all likelihood, it may lead to a strong hierarchy on the Single Market - that is, a strong concentration of economic development in only a small number of advanced EU regions and member states. The proposal to revive and articulate modern types of industrial policies across the EU is a call for comprehensive economic and social restructuring. The 
task of modern industrial policy is to organize and strengthen capabilities of restructuring in the direction of high-productivity activities. Rodrik (2007), one of the leading proponents of modern industrial policy for the twenty-first century, warns that restructuring is not an automatic process but rather requires a collective, deliberative approach: "[I]ndustrial policy is a process of strategic collaboration between the private and public sectors, where the objectives are to identify blockages and obstacles to new investments and to design appropriate policies in response" (Rodrik, 2007, loc 234-45, Kindle edition).

The proposal to broaden the scope and objectives of industrial policies in the existing European legal framework is only one of the first steps toward comprehensive European restructuring, the ultimate goal of which should be to create a more balanced, more inclusive and more pluralistic Europe than we witness within the increasingly restrictive European framework.

\section{REFERENCES}

Best, M. (1990). The new competition - Institutions of industrial restructuring. Harvard University Press.

Bianchi, P., \& Labory, S. (Eds.). (2006). International handbook on industrial policy. Edgar Elgar Publishing.

Cecchini Report. (1988). Europe 1992: The overall challenges. Summary of the report available at: http://aei.pitt.edu/3813/ (visited on September 5, 2013).

Church, C. H., \& Phinnemore, D. (2002). The Penguin guide to the European tTreaties From Rome to Maastricht, Amsterdam, Nice and beyond., Penguin Books.

European Commission (1993). White paper on growth, competitiveness, employment. Brussels.

European Convention (2002). Final report of working group VI on economic governance. Available at: http://european-

convention.eu.int/pdf/reg/en/02/cv00/cv00357.en02.pdf (visited on September 5, 2013).

European Union (2012). Eurostat regional yearbook 2012. Belgium: Publications Office of the European Union. Available at:

http://epp.eurostat.ec.europa.eu/portal/page/portal/publications/regional_yearbook (visited on September 5, 2013).

Fioretos, O. (2001). Sources of multilateral preferences. In P. Hall \& D. Soskice (Eds.), Varieties of capitalism - The institutional foundations of comparative advantage (pp. 213-244). Oxford University Press.

Ha-Joon Chang. (2009). Industrial policy: Can we go beyond an unproductive confrontation? Annual World Bank Conference on Development Economics, Seoul. Available at: http://siteresources.worldbank.org/INTABCDESK2009/Resources/HaJoon-Chang.pdf (visited on September 5, 2013). 
Kok, W. et al. (2003). Jobs, jobs, jobs - Creating more employment in Europe. Report of the Employment Taskforce chaired by W. Kok, Brussels. Available at:

http://www.mol.fi/mol/en/99_pdf/en/90_publications/employment_taskforce_report20 03.pdf (visited on September 5, 2013).

Lothian, T., \& Unger, R. (2011). Crisis, slump, superstition and recovery: A joint-piece. Available at: http://www.law.harvard.edu/faculty/unger/english/pdfs/JOINT_PIECE.pdf (visited on September 5, 2013).

Nahtigal, M. (2013). European regional disparities - The crucial source of European unsustainability. Lex Localis, 11(33), 601-614. Available at:

http://papers.ssrn.com/sol3/papers.cfm?abstract_id $=2248618$

Pelkmans, J. (2011). The case for 'more single market.' CEPS no. 234, Brussels, February 2011.

Pelkmans, J. (2006). European industrial iolicy. In P. Bianchi \& S. Labory (Eds.), International handbook on industrial policy (pp. 45-78). Edgar Elgar Publishing.

Piore, M., \& Sabel, C. (1984). The second industrial divide - Possibilities for prosperity. Basic Books.

Rodrik, D. (2011). The globalization paradox: Democracy and the future of the world economy [Kindle edition]. W.W. Norton \& Company. Retrieved from Amazon.com.

Rodrik, D. (2007). One economics, many recipes: Globalization, institutions, and economic growth [Kindle edition]. Princeton University Press. Retrieved from Amazon.com.

Tsoukalis, L. (2006). What kind of Europe? Oxford University Press.

Unger, R. (2008). Using the crisis to remake the markets. Available at:

http://www.law.harvard.edu/faculty/unger/english/pdfs/UsingTheCrisis.pdf (visited on September 5, 2013).

Unger, R. (2007). Free trade reimagined - The world division of labor and the method of economics. Princeton University Press.

Unger, R. (2001). European constitutionalism - Proposals for an agenda of debate. Harvard Law School. Available at:

http://www.law.harvard.edu/faculty/unger/english/docs/europe1.pdf (visited on September 5, 2013.

Wintour, P., \& Mulholland, H. (2011). Vince Cable: Pure laissez-faire does not work. The Guardian, September 11, 2011.

http://www.theguardian.com/politics/2012/sep/11/vince-cable-laissez-faire-work (visited on September 5, 2013). 